\title{
Sosialisasi Perilaku Hidup Bersih dan Sehat (PHBS) Di SDS Islam "Plus" Al Manshur Banjarbaru
}

\author{
Hilda Irianty ${ }^{1}$, Ridha Hayati ${ }^{2}$, Deni Suryanto ${ }^{3}$ \\ ${ }^{1,2,3}$ Fakultas Kesehatan Masyarakat, Universitas Islam Kalimantan MAB Banjarmasin \\ Email: Hildanafarin@gmail.com
}

Submitted : 07/09/2020

Accepted: 21/09/2020

Published: 24/11/2020

\section{Abstract}

PHBS at school is a set of behaviors practiced by students, teachers and the school community on the basis of awareness as a learning outcome, so that they are able to independently prevent disease, improve their health, and play an active role in creating a healthy environment. The targets and outputs of this service are scientific publications in ISSN journals, publications on social media and the application of PHBS in schools. The method of implementing these activities is to use lecture, discussion and question and answer methods. The implementation of this service was carried out at SDS Islam Al Manshur Banjarbaru with 70 students and 2 homeroom teachers. The stages of this activity are carried out through 3 stages namely the first stage of preparation, the second stage of implementation and the third stage of evaluation. The conclusion obtained after counseling $90 \%$ of students understand about Clean \& Healthy Behavior.

Keyword : PHBS, primary school, socialization, student

\begin{abstract}
Abstrak
PHBS disekolah adalah sekumpulan perilaku yang dipraktikkan oleh peserta didik, guru dan masyarakat lingkungan sekolah atas dasar kesdaran sebagai hasil pembelajaran, sehingga secara mandiri mampu mencegah penyakit, meningkatkan kesehatannya, serta berperan aktif dalam mewujudkan lingkungan sehat. Target dan luaran pengabdian ini adalah publikasi ilmiah pada jurnal ber-ISSN,Pubilkasi di media sosial dan adanya penerapan PHBS disekolah.Metode pelaksanaan kegiatan ini adalah dengan menggunakan metode ceramah,diskusi dan tanya jawab. Pelaksanaan kegiatan pengabdian ini dilaksanakan di SDS Islam Al Manshur Banjarbaru dengan jumlah siswa 70 orang dan 2 orang wali kelas. Adapun tahapan kegiatan ini dilakukan melalui 3 tahap yaitu tahapan pertama persiapan, tahap kedua pelaksanaan dan tahapan ketiga evaluasi. Kesimpulan didapatkan setelah dilakukan penyuluhan $90 \%$ siswa paham mengenai Perilaku Hidup Bersih \& Sehat.
\end{abstract}

Kata Kunci: PHBS, sosialisasi, sekolah dasar, siswa

\section{PENDAHULUAN}

Kemajuan sumber daya manusia di bidang pendidikan tidak bisa terlepas dari beberapa faktor pendukung. Salah satu faktor pendukung kemajuan sumber daya manusia di bidang pendidikan ialah kesehatan individual pelajar. (Kemenkes RI,2016).

PHBS disekolah adalah sekumpulan perilaku yang dipraktikkan oleh peserta didik, guru dan masyarakat lingkungan sekolah atas dasar kesdaran sebagai hasil pembelajaran, sehingga secara mandiri mampu mencegah penyakit, meningkatkan kesehatannya, serta berperan aktif dalam mewujudkan lingkungan sehat. (Kompasiana,2018).

Munculnya sebagai penyakit yang sering menyerang anak usia sekolah (6-10 th), ternyata umumnya berkaitan dengan PHBS, oleh karena itu penanaman nilainilai PHBS di sekolah merupakan kebutuhan mutlak dan dapat dilakukan melalui pendekatan Usaha Kesehatan Sekolah (UKS). (Depkes RI,2008)

Dalam upaya meningkatkan derajat kesehatan disekolah, penerapan PHBS di sekolah sangatlah penting.(Depkes RI,2008). Kasus yang terjadi di mitra ada beberapa masalah yaitu masalah pertama 
ada beberapa murid yang sering sakit terkena penyakit diare yang disebabkan masih banyak yang jajan sembarangan disekolah.

Masalah kedua masih belum adanya kantin sekolah sehingga murid masih jajan diluar sekolah. Masalah ketiga karena penerapan PHBS yang kurang sehingga sekolah ini gagal dapat penghargaan Adiwiyata sekolah sehat. Masalah keempat masih belum tersedianya sabun cuci tangan dan handuk sebagai sarana pelengkap cuci tangan.

Melihat dari beberapa masalah yang ada ditempat mitra, maka Tim pengabdian akan melaksanakan sosialisasi PHBS di SDS Islam Al Manshur Banjarbaru.

Dilihat dari analisis situasi masalah, permasalahan mitra antara lain ;Belum adanya kantin sehat yang disediakan oleh sekolah SDS Islam Al Manshur di dalam lingkungan sekolah. Anak murid masih banyak yang jajan sembarangan diluar sekolah sehingga ada beberapa anak yang sering sakit dan tidak sekolah. Penerapan PHBS yang masih kurang di lakukan di SDS Islam Al Manshur. Masih belum tersedianya sabun cuci tangan tangan dan handuk sebagai sarana pelengkap cuci tangan.

Dilihat dari beberapa masalah yang didapat dari mitra, maka diberikan beberapa solusi, antara lain : Dari pihak sekolah menyediakan kantin sehat, sehingga seluruh murid bisa jajan dikantin yang disediakan oleh sekolah. Siswa tidak dipaksa membeli jajan atau makanan dikantin, tapi menyadari sendiri jajan disini sudah bersih dan memenuhi standar layak. Yang perlu diperhatikan adalah makanan yang banyak mengandung bahan berbahaya seperti pewarna, pengawet, pengenyal, dan sejenisnya. Dengan adanya disediakan kantin sehat dilingkungan sekolah maka seluruh murid tidak jajan sembarangan diluar sekolah, maka dari itu bisa mengurangi murid terkena penyakit.
Upaya meningkatkan penerapan PHBS disekolah perlu adanya koordinasi antara pihak sekolah dengan berbagai lintas sektor untuk membuat kebijakan penerapan PHBS di sekolah dan menetapkan penanggung jawab PHBS disekolah disertakan pegawasannya.

Untuk menunjangnya, sekolah harus menyediakan sabun dan handuk sebagai sarana pelengkap cuci tangan. Ingatkan siswa untuk mencuci tangan tiap menjelang dan sesudah istirahat, selesai melakukan pekerjaan,selesai bermain dan menyentuh makanan.

\section{TARGET DAN LUARAN}

Khalayak sasaran yang dijadikan untuk kegiatan ini adalah Siswa sebanyak 70 orang dan 2 Wali Kelas. Luaran kegiatan ini adalahpublikasi ilmiah pada jurnal berISSN,Pubilkasi di media sosial dan adanya penerapan PHBS disekolah.

\section{METODE PELAKSANAAN}

Metode yang digunakan dalam pengabdian ini adalah metode ceramah, diskusi dan tanya jawab. Adapun tahapan dalam pelaksanaan kegiatan ini meliputi : Persiapan awal dalam pelaksanaan sosialisasi dimulai dari persiapan izin kesekolah, Pelaksanaan kegiatan sosialisasi dengan memberikan materi tentang PHBS di sekolah dan Evaluasi kegiatan sosialisasi

Partisipasi mitra dalam program sosialisasi PHBS ini sangat mendukung dengan adanya kegiatan ini sehingga baik kepala sekolah,guru, siswa/i dapat mengetahui beberapa indikator PHBS disekolah dengan harapan terwujudnya sekolah sehat.

\section{HASIL DAN PEMBAHASAN}

Pelaksanaan kegiatan pengabdian ini dilaksanakan di SDS Islam Al Manshur Banjarbaru dengan jumlah siswa 70 orang dan 2 orang wali kelas. Adapun tahapan kegiatan ini dilakukan melalui 3 tahap yaitu 
tahapan pertama persiapan, tahap kedua pelaksanaan dan tahapan ketiga evaluasi. Tahapan pertama persiapan yaitu permintaan izin kepada pihak sekolah untuk melaksanakan kegiatan pengabdian ini. Tahap kedua yaitu pelaksanaan. Pelaksanaan pengabdian ini memberikan sosialisasi kepada siswa tentang Perilaku Hidup Bersih dan Sehat (PHBS).

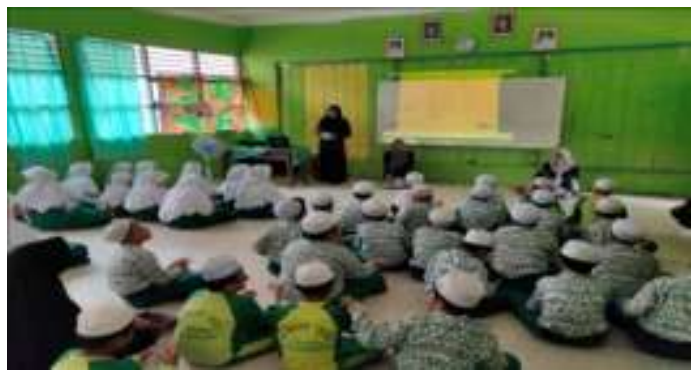

Gambar 1. Memberikan Sosialisasi Tentang PHBS

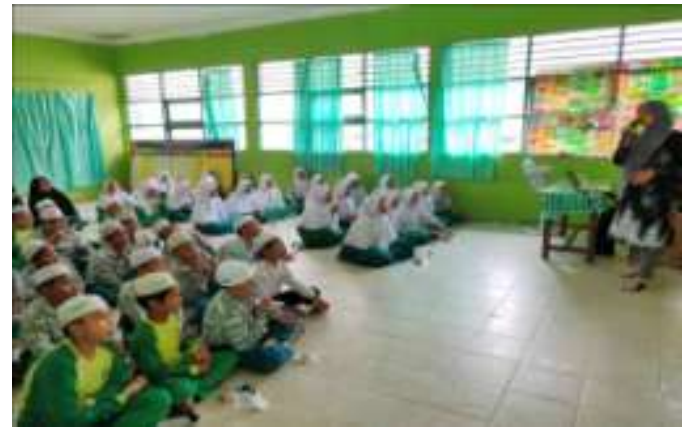

Gambar 2. Memberikan Sosialisasi Tentang PHBS

Setelah diberikan penyuluhan,di lanjutkan dengan diskusi dan tanya jawab.

Acara pengabdian ini diakhiri dengan ucapan terima kasih kepada guru-guru yang telah membantu dalam pelaksanaan kegaitan ini.

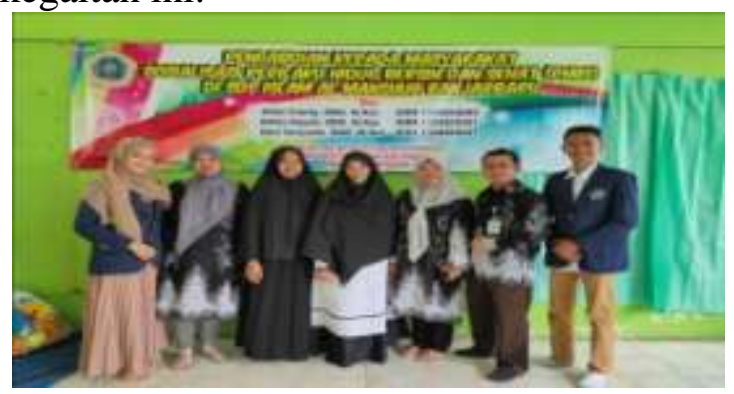

Gambar 3. Foto Bersama

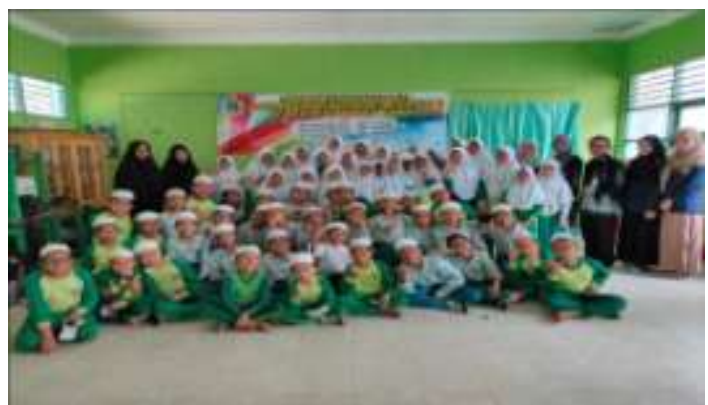

Gambar 4. Foto Bersama

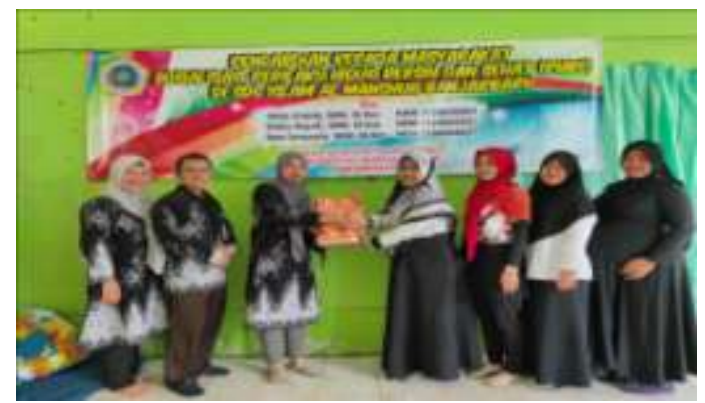

Gambar 5. Foto Bersama dan Ucapan TerimaKasih

Tahap ketiga yaitu evaluasi. Evalusi dilaksanakan setelah 5 hari pelaksanaan kegiatan sosialisasi. Dari hasil evaluasi yang dilakukan kepada 10 siswa, $90 \%$ siswa paham mengenai PHBS di sekolah, tetapi siswa masih lupa tentang arti dari PHBS. Kebanyakan mereka menjawab arti dari PHBS adalah Penerapan Hidup Bersih dan Sehat.

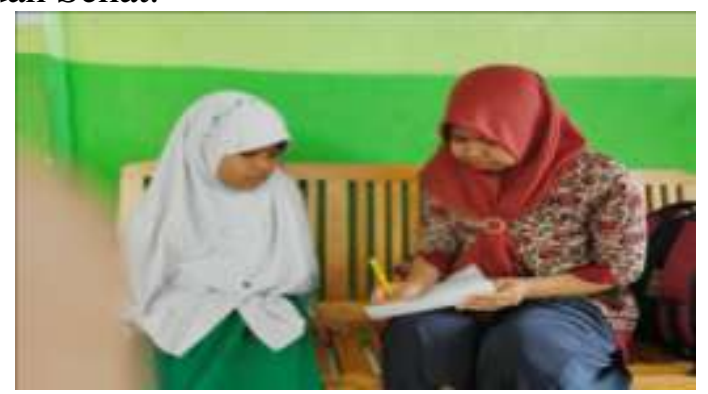

Gambar 6. Foto Evaluasi

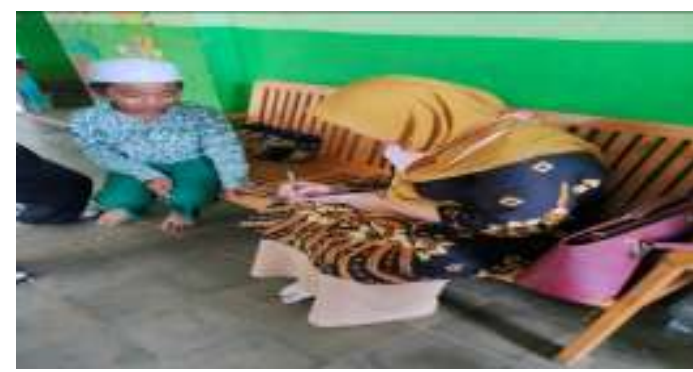

Gambar 7. Foto kegiatan 


\section{KESIMPULAN DAN SARAN}

\section{Kesimpulan}

Metode yang digunakan dalam pengabdian ini adalah metode ceramah, diskusi dan tanya jawab dengan khalayak sasaran 70 siswa dan 2 wali kelas.

Setelah dilakukan sosialisasi $90 \%$ siswa paham mengenai Perilaku Bersih \& Sehat.

\section{Saran}

Setelah dilakukannya kegiatan ini disarankan kepada pihak sekolah agar selalu ada jadwal penyuluhan yang berkaitan dengan kesehatan untuk anak sekolah. Dengan bekerja sama petugas kesehatan.Pihak sekolah juga harus menyediakan sabun cuci tangan dan handuk.

\section{UCAPAN TERIMAKASIH}

Ucapan terima kasih kepada Universitas Islam Kalimantan MAB Banjarmasin yang telah mendanai kegiatan pengabdian ini, kepada temen dan mahasiswa yang telah membantu kegiatan ini,serta kepada kepala sekolah dan guruguru SDS Islam "plus" Al Mannshur Banjarbaru.

\section{DAFTAR PUSTAKA}

Depkes, RI. 2018.Majalah Interaksi Informasi dan Referensi Promosi Kesehatan; Perilaku Hidup Bersih dan Sehat (PHBS) di Sekolah.(https://puskesmasbatuputi hberau.wordpress.com/promkes/inf o-kesehatan/perilaku-hidup-bersihdan-sehat-phbs-di-sekolah/). Di akses 23 September 2019

Kemenkes, RI, 2016. PHBS. (Http://promkes.kemkes.go.id/phbs ). Di Akses 23 September 2019

Panduan, Mengajar. 2017.Indikator Perilaku Hidup Bersih dan Sehat (PHBS) di Sekolah. (https://www.panduanmengajar.co $\underline{\mathrm{m} / 2017 / 04 / \text { indikator-perilaku- }}$ hidup-bersih-dan-sehat-disekolah.html). Di akses 23 September 2019

Kompasiana. 2018. Pentingnya Penerapan PHBS

$d i$

Sekolah. (https://www.kompasiana. com/ahmadyudi/5a5dfc7bcbe5231f b42cbd23/pentingnya-penerapanphbs-di-sekolah). Di akses 23 September 2019 